\title{
MANAJEMEN STOK INDUK PENJENIS PADA POPULASI SINTETIK UDANG GALAH HASIL SELEKSI
}

\author{
Lies Emmawati Hadie"), Wartono Hadie*), Irin Iriana Kusmini*), Jaelani"), Sularto*), \\ dan Yayan Hikmayani* '
}

\begin{abstract}
ABSTRAK
Populasi sintetik udang galah dibentuk dengan tujuan untuk meningkatkan keragaman aditif. Keragaman genetik dapat dieksploitasi dengan metode seleksi. Seleksi dilaksanakan berdasarkan karakter proporsi karapas terhadap panjang badan. Setelah melalui program seleksi, telah dihasilkan stok induk penjenis yang memiliki keragaman yang baik. Oleh karena itu diperlukan perbanyakan stok induk penjenis yang akan dipersiapkan sebagai kandidat untuk dilepas. Pemijahan induk udang dilakukan secara alami dengan metode pemijahan secara random. Teknik reproduksi yang dilakukan adalah pen spawning dengan rasio seks 1: 1. Pemeliharaan larva udang galah dilakukan dengan metode air jernih tanpa air plankton. Pendederan fase I dilaksanakan di dalam bak beton dan selanjutnya dilakukan pendederan II di kolam. Fase pembesaran udang dilakukan di dalam kolam tanah yang berlangsung selama empat bulan. Hasil penelitian menunjukkan bahwa stok penjenis yang diperbanyak memiliki keragaman genetik yang baik. Kesimpulan ini didukung dengan data kuantitatif seperti jumlah individu absolut (Nc) yang mencapai 416, nilai efektive population size adalah 55,18, laju inbreeding (delta F) sebesar 0,0091 dan alel yang terpelihara dari F1 kepada F2 yang mencapai 99,04\%.
\end{abstract}

ABSTRACT: Management of great grand parents stock of synthetic population of giant freshwater by selection method. By : Lies Emmawati Hadie, Wartono Hadie, Irin Iriana Kusmini, Jaelani, Sularto, and Yayan Hikmayani.

Synthetic population of giant freshwater was formed to increas the aditif variation. The genetic variation had been exploited by selection method. Selection was conducted based on the proportion of carapace to body length character. Long term of selection program has produced great grandparent stock with high genetic of variance. After that the multiplication of great grandparents stock is important to conduct because they are candidates to release. Natural breeding of great grandparent stock were conducted by random mating. The reproduction technique used pen spawning with sex ratio of 1:1. Larval rearing of giant freshwater prawn used clear water system without plankton. The first nursery of post-larvae was conducted in concrete tank and fingerling production on earthen ponds. The grow-out of giant freshwater prawn were done on earhen ponds for four months. Result of this experiment showed that the multiplication of great grandparent stock had a hight variation of genetic. The conclusion based on the quantitative data such as the absolute individual size ( $\mathrm{Ne}$ ) were reached 416 , the effective population size is 55.18 , inbreeding rate $(F) 0.0091 \%$ and keeping allele of F1 generation to F2 of synthetic population $99.04 \%$.

\section{KEYWORDS: $\quad$ great grandparent stock, selection, giant freshwater prawn, variation}

\section{PENDAHULUAN}

Populasi udang galah di Indonesia bersifat unik, dan berdasarkan distribusi geografisnya diduga Indonesia menjadi center of origin dari udang galah. Fakta ini didukung oleh hasil penelitian Holthuis $(1950,1980)$ yang memberikan informasi bahwa terdapat 19 spesies dari kerabat udang galah marga Macrobrachium yang tersebar hampir di seluruh Kepulauan Indonesia

Berdasarkan penelitian Stelmach (1980) ternyata populasi udang galah dapat dikelompokkan menjadi dua grup, yakni grup barat dan timur yang dibatasi oleh garis imajiner Wallace. Hasil penelitian yang dikemukakan oleh Stelmach (1980) tersebut akan sangat membantu dalam mengarahkan breeding program pada udang galah. Dalam upaya perbaikan mutu genetik pada udang galah, beberapa populasi udang galah dari grup barat dan timur telah dievaluasi sehubungan dengan keragaan produksinya. Dalam hal pertumbuhan ternyata tidak berbeda nyata dari kedua grup tersebut (Hadie et al., 1992). Selanjutnya evaluasi heritabilitas untuk karakter panjang karapas pada populasi Cimanuk, Cimandiri, dan Walanae memperlihatkan nilai yang tinggi. Kemudian karakter panjang karapas tersebut mulai diseleksi dengan menghasilkan respon positif (Hadie et al., 1993) Populasi udang galah dari Kalipucang (Jabar), juga memperlihatkan respon yang positif sewaktu diimplementasikan dengan metode indeks seleksi (Hadie

Peneliti pada Balai Penelitian Perikanan AirTawar 
et al., 1998). Untuk mendukung breeding program yang berkelanjutan pada udang galah, maka ditempuh program seleksi dengan memanfaatkan potensi dari masing-masing koleksi dalam bentuk populasi sintetik.

Pada dasarnya populasi sintetik udang galah ini dibentuk dari beberapa komponen sub-populasi dan telah terbukti memiliki keunggulan yaitu dalam karakter proporsi kepala dan badan yang lebih kecil. Sebagai tindak lanjut dari penelitian sebelumnya, maka induk penjenis udang galah yang telah diperoleh perlu diperbanyak untuk mempertahankan keragaman genetik di dalam populasi tersebut. Konsep yang perlu dikembangkan dalam perbanyakan stok induk penjenis ini adalah mengatur manajemen induk dengan menggunakan prinsip keseimbangan genetik dalam populasi tersebut. Salah satu di antaranya adalah dengan menjaga stabilitas jumlah absolut populasi (Nc) serta mempertahankan jumlah populasi efektif dalam kisaran angka yang cukup besar. Menurut pedoman dari FAO, jumlah populasi efektif di dalam manajemen jangka pendek adalah 50 dan untuk upaya konservasi keragaman genetik dalam jangka panjang memerlukan 500 individu. Di dalam rangka memenuhi kebutuhan ini maka sangat penting untuk memperbanyak stok induk penjenis yang nantinya akan dikembangkan sebagai populasi kandidat untuk direlease sebagai galur harapan

Tujuan dari penelitian adalah mengembangbiakkan stok induk penjenis untuk mempertahankan kelestarian populasi sintetik udang galah hasil seleksi kemudian akan menjadi kandidat release udang galah.

\section{BAHAN DAN METODE}

\section{Breeding dan Manajemen Induk}

Induk penjenis udang galah yang digunakan dalam penelitian ini merupakan F1 dari populasi sintetik hasil seleksi. Pemijahan induk penjenis dari populasi sintetik dilakukan secara alamiah dan untuk pemijahan indukinduk tersebut dilakukan secara random (random mating). Teknik reproduksi dilakukan dengan metode pen spawning dengan rasio seks 1:1. Teknik ini akan menghasilkan populasi yang baik secara genetik (Tave, 1986).

Induk-induk diaklimatisasi di dalam bak terkontrol. Selanjutnya diaplikasikan metode pen spawning setelah diperoleh induk betina dan jantan yang siap memijah.

\section{Masa Inkubasi dan Pemeliharaan Larva Udang Galah}

Induk-induk yang telah memijah kemudian dikarantinakan di dalam bak terkontrol, agar proses inkubasi telur dapat berlangsung dengan baik.
Pemeliharaan larva udang galah dilakukan dengan menggunakan metode air jernih (clear water system) dengan salinitas $8 \%-12 \%$ (Aquacop, 1977; 1983). Bak pemeliharaan larva berukuran $600 \mathrm{~L}$. Bak pemeliharaan larva ini dilengkapi dengan thermostat heater untuk menjaga stabilitas media pada temperatur $28^{\circ} \mathrm{C}$ $31^{\circ} \mathrm{C}$. Pakan larva yang diberikan adalah nauplii Artemia dan pakan buatan yang diberikan sesuai dengan dosis yang dibutuhkan (Aquacop, 1977). Pemeliharaan larva udang berlangsung selama 35 hari hingga mencapai pasca-larva. PL yang dihasilkan dari tahapan pemeliharaan. Larva kemudian diadaptasikan ke dalam media air tawar secara bertahap, yang selanjutnya dipelihara pada tahapan pendederan

\section{Pendederan I pada Pasca-larva (PL)}

Pendederan pasca-larva udang galah dilakukan di dalam bak beton berukuran $18 \mathrm{~m}^{2}$ hingga mencapa juvenile (yuwana). Padat tebar yang digunakan dalam pendederan adalah 250 ekor/m² (Hadie et al., 1992). Pakan yang digunakan dalam tahapan ini adalah pakan udang dengan kadar protein 36,6\% dengan tingkat ransum sebanyak $10 \%$ bobot populasi per hari. Pendederan I pasca-larva udang galah dilakukan selama 30 hari di Inlitkanwar Pasar Minggu. Jakarta.

\section{Pendederan II PL sampai Menghasilkan Ywana Udang Galah}

Pendederan pasca-larva dilaksanakan di kolam tanah berukuran $400 \mathrm{~m}^{2}$ di Balitkanwar Sukamandi. Kondisi perkolaman adalah sistem air mengalir untuk menjamin kualitas air tetap baik sesuai dengan kriteria New (1990), yakni pH (7-8), kesadahan total (40-150 mg/L CaCO 3 ), Oksigen (5-6 mg/L) untuk memungkinkan semua proses biologi yang terjadi selama penelitian pada kondisi yang optimum. Pakan buatan untuk pembesaran menggunakan pakan udang dengan kadar protein 36,6\% dengan tingkat ransum $5 \%$ bobot populasi per hari. Fase pendederan II dilaksanakan selama 30 hari.

Strategi pendederan ini dilaksanakan untuk mempersiapkan yuwana udang galah yang telah beradaptasi dengan lingkungan air tawar. Hal ini diperlukan untuk menghindari tingginya mortalitas pada tahap pembesaran.

\section{Pembesaran}

Tahap pembesaran yuwana udang galah dilaksanakan di kolam air tawar berukuran $400 \mathrm{~m}^{2}$ di Balitkanwar Sukamandi. Kepadatan udang adalah 5 ekor $/ \mathrm{m}^{2}$. Pakan yang diberikan berupa pelet dengan kadar protein $37,0 \%$ dengan ransum harian 15\% pada bulan pertama, $10 \%$ pada bulan ke dua dan 
selanjutnya 5,0\% per hari pada bulan berikutnya. Fase pembesaran udang galah berlangsung selama empat bulan

\section{Pengamatan Kualitas Air}

Kualitas air di kolam dipantau secara periodik yaitu dua minggu sekali untuk mengetahui parameter-parameter penting yang mendukung pertumbuhan udang galah secara optimal. Parameter-parameter yang diamati adalah temperatur air dan oksigen terlarut pada pk. 6.00 dan pk.16.00, pH, daya menggabung asam (DMA), $\mathrm{CO}_{2}$, fosfat, nitrit, nitrat, sulfat, amonium, Mg. Ca bahan organik, kesadahan total, dan amonia.

Metode yang digunakan dalam analisis kualitas air sebagai berikut

a. Penentuan kadar oksigen terlarut dengan cara titrasi menggunakan metode Winkler.

b. pH air diukur menggunakan cairan indikator dalam bentuk reagent kit.

c. Penentuan kadar nitrit dan amonia menggunakan metode Strickland dan Pearsons.

d. Suhu air diukur menggunakan termometer air raksa.

e. Kadar bahan organik dianalisis dengan metode permanganometri

f. Kadar fosfat dianalisis dengan metode kalorimetri.

g. Kadar kesadahan air dianalisis dengan metode kompleksiometri

Sehubungan dengan kualitas daging udang, maka analisis dilakukan dengan metode Kjeldahl untuk kadar protein, metode ekstraksi soxhlet untuk kadar lemak dan metode fiber tag untuk analisis serat kasar.

\section{Metode dan rumus perhitungan parameter genetik}

Perhitungan Effective Population Size (EPS) dihitung berdasarkan rumus:

$$
E P S=8 \mathrm{~N} / \mathrm{V}_{\mathrm{km}}+\mathrm{V}_{\mathrm{kf}}+4
$$

dengan: $N$ adalah jumlah individu yang siap memijah, $V_{k m}$ adalah varian dari jumlah famili jantan; $V_{k f}$ adalah varian dari jumlah famili betina (Falconer \& Mackay, 1996).

\section{Laju inbreeding dihitung berdasarkan rumus}

$$
\text { delta } F=3 / 32 \mathrm{~N}_{m}+1 / 32 \mathrm{~N}_{f}
$$

dengan: Delta $\mathrm{F}$ adalah laju inbreeding, $\mathrm{N}_{\mathrm{m}}$ adalah jumlah individu jantan dan $\mathrm{N}_{\mathrm{f}}$ ialah jumlah individu betina (Falconer \& Mackay, 1996).

Rumus yang digunakan untuk menghitung proporsi keragaman genetik adalah:

$$
P=1-(1 / 2 \mathrm{Ne})
$$

dengan: $P$ adalah proporsi keragaman genetik yang terpelihara; Ne adalah jumlah populasi efektif (EPS) (Primack et al., 1998).

Pengukuran dressing percentage adalah ukuran antara rasio panjang karapas dan panjang badan dikalikan 100\% (Tave, 1986).

\section{HASIL. DAN BAHASAN}

Berdasarkan hasil penelitian sehubungan dengan perbanyakan stok induk penjenis, maka telah diperoleh populasi induk dengan karakter populasi seperti yang dicantumkan dalam Tabel 1

Dari karakter populasi yang tercantum dalam Tabel 1, dapat diketahui bahwa variasi ukuran morfometrik pada induk jantan lebih besar dibandingkan dengan induk betina. Hal ini dapat diketahui dari koefisien variasi pada induk jantan yang berkisar antara 6,7$56,67 \%$. Pada karakter morfometrik betina hanya mencapai $5,77-27,18 \%$. Hal yang sama terjadi pula pada kisaran standar deviasi. Populasi induk jantan memiliki nilai 0,83-35,41 dan induk betina mencapai $0,43-7,61$. Data ini menunjukkan bahwa keragaman gen dalam induk jantan relatif lebih tinggi dibanding induk betina.

Sehubungan dengan nilai skewness, maka nilai yang terdapat pada induk jantan berkisar antara 0,601,60 dan induk betina mencapai 0,48-1,67. Apabila dinilai dari nilai skewness, maka populasi jantan dan betina memperlihatkan model populasi yang positif (Sudjana, 1975; Dayan, 1986). Indikasi ini memperlihatkan bahwa karakter morfometrik pada induk jantan dan betina relatif sedikit yang mempunyai nilai makin besar. Dengan demikian dalam hal karakter morfometrik tidak terdapat perbedaan yang mencolok antara kedua jenis seks tersebut. Kelompok induk jantan dan betina sama-sama memiliki model populasi yang bersifat positif dengan kemiringan ke arah kanan (Tabel 1). Hal ini berarti bahwa induk jantan dan betina memiliki karakter yang terkonsentrasi pada nilai yang moderat baik untuk ukuran panjang maupun bobotnya

Untuk memperjelas karakter populasi induk udang galah, maka analisis dilanjutkan dengan menganalisis koefisien kurtosis dari karakter morfometrik. Sehubungan dengan nilai kurtosis, induk jantan mempunyai nilai 0,27-2,52. Oleh karena itu karakter morfometrik induk jantan menunjukkan distribusi yang bersifat platikurtis yang mempunyai kurva yang mendatar. Induk betina sedikit berbeda kondisinya dengan kisaran nilai kurtosis mencapai 1,7-4,2 Namun pada karakter bobot, induk betina memperlihatkan distribusi yang bersifat leptokurtis, tetapi dalam karakter panjang standar, total dan karapas 
Tabel 1. Karakter populasi stok induk penjenis udang galah yang meliputi bobot (g), panjang total (cm), panjang standar $(\mathrm{cm})$, panjang karapas $(\mathrm{cm})$, fekunditas (butir), dan daya tetas (\%)

Table 1. Character of great grandparent stocks population including weight $(\mathrm{g})$ total length $(\mathrm{cm})$, standard length $(\mathrm{cm})$, carapace length $(\mathrm{cm})$, fecundity (eggs), and hatching rate (\%)

\begin{tabular}{|c|c|c|}
\hline $\begin{array}{l}\text { Parameter karakter } \\
\text { Parameter of trait }\end{array}$ & $\begin{array}{l}\text { Induk jantan } \\
\text { Male of brood stock }\end{array}$ & $\begin{array}{c}\text { Induk betina } \\
\text { Female of broodstock }\end{array}$ \\
\hline \multicolumn{3}{|l|}{ Bobot $(g) /$ Weight $(g)$} \\
\hline Rata-rata + SD / Average $\pm S D$ & 62.36 & $28.0+7.61$ \\
\hline Maksimum / Maximum & 143.70 & 54.10 \\
\hline Minimum / Minimum & 27.40 & 16.00 \\
\hline Koefisien variasi (\%) / Coefficient of variation & 56.77 & 27.18 \\
\hline \multicolumn{3}{|l|}{$\begin{array}{l}\text { Skewness / Skewness } \\
\text { Kurtosis / Kurtosis }\end{array}$} \\
\hline Kurtosis / Kurtosis & & \\
\hline \multicolumn{3}{|l|}{ Panjang total $(\mathrm{cm}) /$ Total length $(\mathrm{cm})$} \\
\hline Rata-rata + SD / Average $\pm S D$ & $16.1+2.57$ & $12.38+1.14$ \\
\hline Maksimum / Maximum & 23.50 & 16.50 \\
\hline Minimum / Minimum & 11.00 & 11.20 \\
\hline Koefisien variasi $(\%)$ / Coefficient of variation & 15.99 & 9.23 \\
\hline Skewness / Skemness & 0.74 & 1.53 \\
\hline Kurtosis / Kurtosis & 0.08 & 3.42 \\
\hline \multicolumn{3}{|l|}{ Panjang standar $(\mathrm{cm}) /$ Standart length $(\mathrm{cm})$} \\
\hline Rata-rata + SD / Average $\pm S D$ & $12.39+0.83$ & $3.18+0.43$ \\
\hline Maksimum / Maximum & 6.80 & 12.70 \\
\hline Minimum / Minimum & 3.00 & 7.50 \\
\hline Koefisien variasi $(\%)$ / Coefficient of variation & 18.11 & 10.37 \\
\hline Skewness / Skemmess & 0.61 & 1.27 \\
\hline Kurtosis / Kurtosis & 0.20 & 1.80 \\
\hline \multicolumn{3}{|l|}{ Panjang karapas $(\mathrm{cm}) /$ carapace length $(\mathrm{cm})$} \\
\hline Rata-rata + SD / Average $\pm S D$ & $4.58+0.83$ & 3.18 \\
\hline Maksimum / Maximum & 6.80 & 12.70 \\
\hline Minimum / Minimum & 3.0 & 7.50 \\
\hline Koefisien variasi $(\%)$ / Coefficient of variation & 18.11 & 10.37 \\
\hline Skewness / Skewness & 0.61 & 1.27 \\
\hline Kurtosis / Kurtosis & 0.20 & 1.80 \\
\hline \multicolumn{3}{|l|}{ Rasio kepala/badan(\%) / Ratio of head/body(\%) } \\
\hline Rata-rata + SD / Average $\pm S D$ & $36.97+2.46$ & $33.92+1.96$ \\
\hline Maksimum / Maximum & 46.28 & 41.50 \\
\hline Minimum / Minimum & 33.33 & 29.80 \\
\hline Koefisien variasi $(\%)$ / Coefficient of variation & 6.71 & 5.77 \\
\hline Skewness / Skewness & 0.60 & 0.49 \\
\hline Kurtosis / Kurtosis & 1.70 & 1.70 \\
\hline \multicolumn{3}{|l|}{ Fekunditas(butir) / Fecundity (eggs) } \\
\hline \multicolumn{3}{|l|}{ Daya tetas (\%) / Hatching rate (\%) } \\
\hline Rata-rata + SD / Average $\pm S D$ & & 44.05 \\
\hline
\end{tabular}

menunjukkan distribusi yang bersifat platikurtis (Pasaribu, 1975)

Berdasarkan koefisien kurtosis tersebut di atas, maka karakter induk jantan memiliki pencaran frekuensi yang tersebar merata. Namun berbeda halnya dengan karakter induk betina yang mempunyai pencaran frekuensi yang hanya berkisar pada nilai rata-rata hitung. Data ini memperlihatkan bahwa induk jantan memiliki karakter yang lebih potensial dibandingkan dengan induk betina karena mempunyai pencaran frekuensi yang lebih luas. Sehingga kondisi ini memungkinkan untuk berkembang lebih baik 
dalam mewariskan sifat genetik yang dimilikinya kepada generasi selanjutnya.

Sesuai dengan tujuan dari kegiatan penelitian ini yaitu mengembangbiakkan stok induk penjenis untuk mempertahankan kelestarian populasi sintetik hasil seleksi, maka aspek manajemen induk menjadi faktor yang penting. Berkaitan dengan aspek manajemen induk dalam populasi sintetik, parameter-parameter yang langsung berhubungan dengan faktor tersebut disajikan dalam Tabel 2 mempertahankan eksistensinya (Meffe \& Caroll, 1994). Menurut kesepakatan dari pakar-pakar genetik, heterosigositas berhubungan dengan fitness. Hal itu berarti bahwa tingkat heterosigositas akan mempengaruhi kondisi fitness dalam suatu individu. Fitness meliputi tiga aspek yang penting dalam mempertahankan kelestarian suatu spesies yaitu harapan hidup (longevity), fertilitas, dan fekunditas. Untuk mengetahui potensi heterosigositas dalam populasi udang galah, diukur nilai delta F (tingkat inbreeding)

Tabel 2. Status manajemen induk udang galah dalam populasi sintetik, yang meliputi jumlah absolut individu (Nc), jumlah populasi efektif (EPS), rasio seks, laju inbreeding, dan proporsi keragaman genetik yang terpelihara dari generasi F1 ke F2

Table 2. Status of broodstock management of synthetic population as follows absolut population size (Nc). effective population size (EPS), sex-ration, inbreeding rate, and proportion of rare of genetic variance of generation of $F 1$ to $F 2$

\begin{tabular}{lc}
\hline \multicolumn{2}{c}{ Parameter (Parameter) } \\
\hline Jumlah absolut individu (Absolut individu size (NC)) & 416.0 \\
Jumlah populasi efektif (Effective population size (EPS) & 55.18 \\
Rasio seks (Sex ratio) & $1: 2.4$ \\
Laju inbreeding (Inbreeding rate (F\%) & 0.0091 \\
Proporsi alel yang terpelihara dari F1 ke F2 (Proportion of & 99.04 \\
keeping allele of F1 to F2) (\%)
\end{tabular}

Berdasarkan data yang tercantum dalam Tabel 2 , maka tergambar kondisi gen-gen yang terdapat di dalam populasi sintetik tersebut. Suatu populasi spesies akan mampu bertahan apabila memiliki jumlah absolut individu (Nc) dengan kisaran angka 50-500 ekor individu (Primack et al., 1998). Namun untuk spesies yang memiliki fluktuasi yang sangat tinggi dalam jumlah populasinya, maka untuk mempertahankan kelestarian spesies tersebut membutuhkan Nc minimal 1.000 ekor individu (Lande cit. Primack, 1998). Berdasarkan hal itu, maka populasi udang galah termasuk spesies yang tidak terlalu tinggi tingkat fluktuasi jumlah dalam populasinya. Dengan demikian stok induk penjenis yang telah diperoleh, memungkinkan untuk terus bertahan karena Nc populasi udang galah mencapai nilai 416,0 individu.

Apabila ditinjau dari segi EPS, keragaman yang terdapat dalam populasi udang ini relatif cukup tinggi yaitu nilai EPS mencapai 55,18. Nilai EPS itu merupakan indikasi mengenai kesiapan dan keberhasilan induk jantan dan betina dalam sistem pembiakannya. Nilai EPS dengan kisaran angka 50 cukup untuk mempertahankan keragaman gen dalam jangka pendek (Primack et al., 1998).

Sehubungan dengan heterosigositas yang merupakan indikasi yang berkaitan dengan potensi alel dalam suatu populasi, maka populasi itu sanggup yang pada populasi induk mencapai nilai 0,0091\%. Data ini mempelihatkan bahwa populasi induk udang yang berasal dari populasi sintetik ini mengalami penurunan heterosigositas sebesar 0,0091\% untuk setiap generasi. Penurunan heterosigositas ini terjadi karena berkurangnya kuantitas dari alel yang frekuensinya jarang (rare alel). Namun penurunan sebesar 0,0091\% masih relatif aman untuk mempertahankan populasi udang tersebut, karena proporsi keragaman genetik yang masih terpelihara dari generasi $\mathrm{F} 1$ kepada generasi $\mathrm{F} 2$ masih relatif tinggi yaitu sebesar 99,04\% (Tabel 2). Perlu dikemukakan bahwa siklus hidup udang galah relatif singkat yaitu interval generasi adalah lima bulan. Jadi dengan proporsi gen yang terpelihara mencapai angka $99,04 \%$, maka hal ini tidak akan menyebabkan degradasi gen dalam populasi udang karena masa interval generasi relatif singkat. Berkaitan dengan kualitas daging udang galah yang terkandung dalam populasi induk, maka hasil analisis proksimat dikemukakan di dalam Tabel 3.

Kualitas daging udang dari populasi sintetik ternyata relatif baik mutunya. Hal ini tergambarkan dari hasil analisis proksimat yaitu protein mencapai $65,29 \%$, berarti udang galah dapat menjadi sumber protein hewani yang bermutu. Di samping itu kandungan lemak mencapai 8,7\% dan NFE 20,92\%, 
Tabel 3. Analisis proksimat kualitas daging udang galah berdasarkan kondisi kerlng $105^{\circ} \mathrm{C}$ Table 3. Proximate analysis of flesh quality of giant freshwe ar prawn at dry condition of $105^{\circ} \mathrm{C}$

\begin{tabular}{lc}
\hline \multicolumn{1}{c}{ Parameter (Parameter) } & K. isentrasi (Consentration) \\
\hline Kadar air (Water content) & (\%) \\
Protein (Crude protein) & 78.26 \\
Lemak (Crude fat) & 65.29 \\
Abu (Crude ash) & 8.70 \\
Serat kasar (Crude fiber) & 4.01 \\
NFE (Nitrogen free extract) & 1.08 \\
\hline
\end{tabular}

nilai ini menggambarkan bahwa udang juga menjadi sumber bahan serat yang baik untuk kehidupan manusia (Tabel 3).

Sehubungan dengan kualitas air didalam kolam pembesaran, data kisaran kualitas air diperlihatkan di dalam Tabel 4.

Berdasarkan kisaran nilai dalam parameter kualitas air di kolam pembesaran udang, maka kondisi air masih dalam batas toleransi untuk kehidupan udang galah (Tabel 4). Di dalam mendukung pertumbuhan udang galah, faktor temperatur air sangat berperan karena udang galah memerlukan suhu yang relatif panas. Suhu air yang dipantau berkisar antara 25,5$29,0^{\circ} \mathrm{C}$, kisaran nilai ini relatif mendukung pertumbuhan udang galah. Demikian pula faktor $\mathrm{pH}$ yang memiliki kisaran 7-8,5 yang termasuk bersifat netral sampai basa, $\mathrm{pH}$ ini sangat mendukung untuk sintasan udang galah.

Kegiatan penelitian untuk memperbanyak stok induk penjenis udang galah dilaksanakan secara beruntun di lingkungan yang sama. Strategi semacam ini dimaksudkan untuk meningkatkan daya adaptasi lokal dari populasi udang tersebut. Daya adaptasi lokal yang baik akan menyebabkan potensi alel yang terdapat di dalam populasi udang dapat lebih di

Tabel 4. Kisaran kualitas air kolam pemeliharaan udang galah yang meliputi temperatur air, oksigen terlarut, $\mathrm{pH}, \mathrm{DMA}$, karbon dioksida, fosfat, nitrat, nitrit, sulfat, amonia, amonium, Mg, Ca, bahan organik, dan kesadahan total

Table 4. Range of water quality of giant freshwater prawn rearing in earthen ponds as follows water temperatur, $\mathrm{pH}$, acid compound, carbon dioxyde, phosphat, nitrate, sulphate, ammonia, ammonium, $\mathrm{Mg}, \mathrm{Ca}$, organic compound, and total of hardness

\begin{tabular}{|c|c|}
\hline Parameter (Parameter) & Kisaran nilai (Range value) \\
\hline \multicolumn{2}{|l|}{ Suhu air (Temperature) $\left({ }^{\circ} \mathrm{C}\right)$} \\
\hline Pk. $6.00(6.00 \mathrm{am})$ & $25.5-26.0$ \\
\hline $\begin{array}{l}\text { Pk. } 6.00\left(6 .{ }^{00} \mathrm{pm}\right) \\
\text { Oksigen terlarut (Dissolve oxygen) (mg/L) }\end{array}$ & $28.5-29.0$ \\
\hline Pk. $6.00(6.00 \mathrm{am})$ & $5.1-5.2$ \\
\hline Pk. $6.00\left(6 .{ }^{00} \mathrm{pm}\right)$ & $7.6-9.6$ \\
\hline $\mathrm{pH}(\mathrm{pH})$ & $70.0-8.5$ \\
\hline DMA (Acid compound) (mg/L) & $48.04-72.06$ \\
\hline $\mathrm{CO}_{2}($ Carbon dioxide $)(\mathrm{mg} / \mathrm{L})$ & $0.0-3.57$ \\
\hline Fosfat (Phosphate) (mg/L)) & $0.119-1.161$ \\
\hline Nitrit (Nitrite) $(\mathrm{mg} / \mathrm{L}))$ & $0.021-0.093$ \\
\hline Niitrat (Nitrate) (mg/L)) & $0.069-0.139$ \\
\hline Sulfat (Sulphate) $(\mathrm{mg} / \mathrm{L}))$ & $2.718-5.651$ \\
\hline Amonium (Ammonium) (mg/L) & $0.960-1.599$ \\
\hline $\mathrm{Mg}$ (Magnesium) (mg/L) & $17.92-43.02$ \\
\hline $\mathrm{Ca}(\mathrm{Ca} / \mathrm{lcium})(\mathrm{mg} / \mathrm{L})$ & $25.53-29.78$ \\
\hline Bahan organik (Organic matter) (mg/L) & $13.90-18.96$ \\
\hline Total hardness (Total of hardness) (mg/L) & $44.67-76.90$ \\
\hline Amonia (Ammonia) (mg/L) & $0.005-0.009$ \\
\hline
\end{tabular}


ekspresikan secara optimal (Falconer, 1981; Meffe \& Carroll, 1994). Dalam jangka panjang daya adaptasi lokal ini akan mencegah terjadinya degradasi gen, dan hal ini juga akan mendukung perbaikan mutu genetik dan kelestarian populasi tersebut. Dalam arti yang lebih luas konsep populasi sintetik akan mengarah kepada pengembangan manajemen genetik yang berorientasi ke masa depan.

\section{KESIMPULAN}

Berdasarkan hasil penelitian yang telah dilaksanakan maka dapat disimpulkan bahwa populasi induk penjenis udang galah hasil seleksi telah layak diusulkan sebagai kandidat varietas udang dengan keistimewaan memiliki proporsi badan lebih besar dan cepat tumbuh

\section{DAFTAR PUSTAKA}

Aquacop. 1977. Macrobrachium rosenbergii culture in Polynesia progress in developing a mass intensive larval rearing in clear wter. Proc. World. Maricult. Soc. \& Avoult. J.W. Lousiana State University. Baton Rouge. $311 \mathrm{pp}$

Aquacop. 1983. Intensive Larval rearing in Clear Water of $M$. rosenbergii at Centre Oceanologique Du Pacifique Tahiti. Hand Book of maricult. Biol.1. Crustacean Aquacult. p. 179-187

Dayan, A. 1986. Pengantar Metode Statistik. Jilid I. LP3ES. Jakarta. p.202-209.

Falconer, D.S. 1981. Introduction to Quantitative Genetics. Longman. London and New York. p.170-181.

Falconer, D.S and Mackay, F.C. 1996. Introduction to Quantitative Genetics. Longman Group Ltd. Malaysia. p:65-71.
Gjeldrem, T. 1996 Construction of Breeding Program in publish. $15 \mathrm{pp}$

Hadie, W., Jaelani, dan Hadie, L.E. 1992. Padat penebaran berbeda dalam usaha pentokolan benih udang galah ( $M$. rosenbergii) dan keragaan produksinya. Pros. Sem. Has. Penel. Perik Air Tawar. Balitkanwar Bogor. p. 153-157

Hadie, L.E., Hadie, W., Jaelani, dan Mulyanti, N. 1993. Pengaruh substrat dan kepadatan pada penampungan pascalarva udang galah dengan sistem resirkulasi. Pros. Sem. Has. Penel. Perik Air Tawar. Balitkanwar Bogor. p.185-192.

Hadie. L.E., Hadie, W., Jaelani, Kusmini, I.I., dan Sudarto.1998. Implementasi indeks seleksi dalam upaya peningkatan pertumbuhan udang galah $(M$. rosenbergii). J. Penelitian Perikanan Indonesia. Vol. IV(1): 47-54

Holthuis, L.B.1950. The Decapoda of the Siboga Expedition. Paul $X$. The Palaemonidae, Sub Family Palaemoninae. E.J. Brill Leiden. 97 pp

Holthuis, L.B.1980. Shrimp and Prawn of the World. An Annotated catalogue of species of interest to fisheries. FAO. Rome. p. 81-117.

Meffe, G.K.A and Carroli, C.R. 1994. Principles of Conservation Biology. Sinaeur Associates, Inc. Publisher. Sunderland, Massachusetts. p. 143-178.

New, M. B. 1990. Freshwater prawn culture. A review, Aquaculture (88):99-143p.

Pasaribu, A. 1975. Pengantar Statistik. Ghalia Indonesia. Medan. 130 pp.

Primack, R.B., Supriatna, J., Indrawan, M., Kartadibrata, P. 1998. Biologi Konservasi. Yayasan Obor Indonesia. Jakarta. p.1-108.

Sudjana. 1975. Statistika. Penerbit Tarsito, Bandung. 487 $\mathrm{pp}$.

Tave, D. 1986. Genetics for Fish Hatchery Managers. AVI. Publishing Co. Inc. Westport. Connecticut. p. 122-145 


\title{
PENGARUH TINGKAT SALINITAS MEDIA PEMELIHARAAN TERHADAP KUALITAS DAGING IKAN MAS (Cyprinus carpio)
}

\author{
Lies Setijaningsih"), Kunto Purnomo, "dan Chairulwan Umar")
}

\begin{abstract}
ABSTRAK
Dalam rangka meningkatkan nilai tambah pada ikan mas, telah dilakukan penelitian untuk mengetahui pengaruh tingkat salinitas terhadap kualitas daging ikan mas. Tingkat salinitas yang dipakai adalah 0, 6, 8, dan $10 \mathrm{ppt}$. Ikan yang digunakan ukuran $100 \mathrm{~g}$, berasal dari kolam air deras dan keramba jaring apung. Kualitas daging ikan mas ditentukan dengan menggunakan parameter tekstur daging dan rasa. Rancangan percobaan yang digunakan adalah rancangan acak lengkap.

Hasil penelitian menunjukkan bahwa perlakuan cara asal budi daya, lama pemeliharaan, dan tingkat salinitas berpengaruh nyata terhadap kualitas daging ikan. Ikan yang berasal dari hasil budi daya kolam air deras mempunyai tekstur daging yang lebih baik. Ikan yang berasal dari kolam air deras menunjukkan tekstur terting $0,72 \mathrm{~kg} / \mathrm{mm}$ pada hari ke-12 dengan salinitas 8 ppt dan ikan yang berasal dari keramba jaring apung menunjukkan tekstur tertinggi $0,661 \mathrm{~kg} / \mathrm{mm}$ pada hari ke-16 dengan salinitas 10 ppt. Salinitas sangat nyata berpengaruh terhadap tekstur dan rasa seperti ditunjukkan oleh kandungan asam amino histidin dan prolin daging ikan mas.
\end{abstract}

ABSTRACT: Influence of salinity levels of culture media on meat quality of common carp. By: Lies Setijaningsih, Chairulwan Umar, dan Kunto Purnomo.

In order to increase value added of common carp, an experiment on the influence of salinity levels of culture media on the texture of common carp meat has been conducted. The salinity levels of culture media used were $0,6,8$, and 10 ppt. One hundred gram of fish harvested from floating cage and running water systems were used. The meat quality was measured from the meat taste and its elasticity. The experimental design applied was completely randomized design.

The result showed that the culture type, culture period, and water salinity levels were significanly affect the quality of carp meat. The meat texture of fish culture in the running water cultured system, i.e. $0.72 \mathrm{~kg} / \mathrm{mm}$ elasticyty, was reached after 12 days rearing at 8 ppt of salinity and the best texture of the fish from floating cage cultured system i.e. $0.61 \mathrm{~kg} / \mathrm{mm}$ elasticity was reached after 16 days rearing at 10 ppt of salinity. Water salinity was significantly affect the texture and taste of carp meat which can be seen on the higher content of histidin and prolin.

KEYWORDS: salinity, texture, taste, common carp

\section{PENDAHULUAN}

Budi daya ikan mas dalam keramba jaring apung maupun kolam air deras sampai saat ini masih mengutamakan produksinya daripada segi kualitas dagingnya. Mutu ikan yang baik ditentukan oleh kualitas dagingnya. Kualitas daging ikan dipengaruhi oleh aspek internal dan eksternal. Aspek internal merupakan sifat yang sulit dikontrol seperti keturunan, umur, jenis kelamin, dan aktivitas fisiologi, sedangkan aspek eksternal dipengaruhi sifat fisik dan kimiawi lingkungan perairan sebagai media hidupnya (Halver, 1972). Salah satu sifat lingkungan yang dapat mempengaruhi aktivitas fisiologi ikan adalah salinitas. Salinitas adalah total konsentrasi garam-garam yang terionisasi atau terlarut dalam air yang disetarakan dengan garam natrium klorida (Knut Schmidt \& Nielsen, 1988). Ikan air tawar yang dipelihara pada media salinitas yang lebih tinggi, di mana konsentrasi garam dalam tubuhnya lebih kecil daripada konsentrasi garam medium, cenderung mengekskresikan air lewat selaput keluar dari tubuh untuk mencapai homeostatis (Nybakken, 1988). Perubahan lingkungan dari air tawar ke lingkungan yang bersalinitas membutuhkan perubahan dalam proses osmoregulasi. Dalam osmoregulasi dalam tubuh ikan diproduksi senyawa yang menyebabkan isotonik dengan lingkungan antara lain asam amino bebas, yang sering disebut dengan depression freezing point. Pengaruh konsentrasi salinitas terhadap kualitas daging ikan air tawar berkorelasi positif dengan tekstur dagingnya. Selain itu dapat meningkatkan nilai organoleptik pada tekstur, rasa, dan bau yang dibuktikan pada percobaan yang dilakukan pada ikan nila merah (Anggawati et al., 1991), dan pada ikan gurami (Setijaningsih, 1999).

Peneliti pada Balai Penelitian Perikanan Air Tawar 
Informasi daya adaptasi ikan mas pada media bersalinitas masih sangat terbatas. Upaya untuk memperbaiki kualitas daging ikan mas melalui pendekatan lingkungan bersalinitas pada tingkat salinitas yang berbeda perlu dicoba. Ikan mas mudah menyesuaikan diri terhadap perubahan suhu, keadaan makanan, dan lingkungan tempat hidupnya (Ardiwinata, 1981). Untuk memberikan nilai tambah pada ikan mas perlu dicoba daya tahannya terhadap berbagai tingkat salinitas. Dalam percobaan ini diuji pengaruh tingkat salinitas terhadap kualitas daging ikan mas.

\section{BAHAN DAN METODE}

\section{Penelitian Pendahuluan}

Penelitian ini dilaksanakan di Laboratorium Nutrisi Balai Penelitian Perikanan Air Tawar Sukamandi selama enam minggu. Empat minggu digunakan untuk penelitian pendahuluan dengan tujuan untuk mengetahui tingkat salinitas yang dapat ditolerir oleh ikan mas untuk hidup yaitu 0, 5, 10, dan 15 ppt. Wadah yang digunakan adalah akuarium berkapasitas $140 \mathrm{~L}$ yang dilengkapi dengan sistem aerasi dari suatu portable blower yang didistribusikan melalui selang plastik. Ikan mas diperoleh dari Balai Benih Ikan di Wanayasa, Purwakarta dengan bobot rata-rata 100 g/ekor. Bagian atas setiap wadah percobaan ditutup dengan jaring untuk mencegah ikan meloncat ke luar.

Periakuan pada penelitian pendahuluan adalah 3 kombinasi acak lengkap pola faktorial dari 2 faktor. Faktor pertama adalah ukuran ikan $100 \mathrm{~g}$ dengan kepadatan 10 ekor/wadah dan faktor kedua adalah air berbeda salinitas yang terdiri atas 4 taraf, yaitu 0 , 5, 10, dan 15 ppt. Setiap kombinasi diulang tiga kali.

\section{Penelitian Lanjutan}

Penelitian selanjutnya adalah untuk mengetahui kadar salinitas yang dapat meningkatkan kualitas daging ikan mas. Perlakuan yang diteliti adalah 24 kombinasi faktorial dari tiga faktor. Faktor pertama adalah media salinitas yang mengacu pada hasil penelitian pendahuluan yang terdiri atas tiga taraf yaitu 6,8 , dan 10 ppt. Faktor ke dua adalah jenis asal habi- tat yang terdiri atas dua taraf, yaitu keramba jaring apung dan kolam air deras. Setiap kombinasi diulang tiga kali. Faktor ke tiga yaitu lama pemeliharaan 4, 8 , 12, dan 16 hari.

Pakan yang diberikan adalah pakan komersial dalam bentuk pelet dengan frekuensi pemberian tiga kali sehari. Banyaknya pakan yang diberikan yaitu sekenyangnya (satiation)

Sisa pakan dan kotoran disifon setiap hari sebelum pemberian pakan pada pagi hari, kemudian dilakukan penambahan air sebanyak yang keluar dari penyifonan. Kondisi lingkungan terutama salinitas tetap diupayakan sesuai dengan perlakuan.

Analisis asam amino dilakukan pada awal dan akhir penelitian, sedangkan karkas dan organoleptik dikerjakan setiap empat hari. Pelaksanaan penilaian organoleptik melalui panel yang bertindak sebagai instrumen. Panel terlatih sebanyak 3-5 orang. sedangkan panel tidak terlatih terdiri atas 15-25 orang (Soekarto et al., 1985). Dalam pelaksanaan penilaian organoleptik digunakan lembar penilaian dengan uji skoring. Pengamatan parameter tekstur daging ikan mas menggunakan metode pengukuran objektif dengan alat ukur teksturometer instron tipe Warner Bratzler meat shearyang akan menghasilkan grafik dengan satu titik puncak "nilai kekerasan" dengan satuan $\mathrm{kg}$, dan kekenyalan dengan satuan $\mathrm{mm}$. Hasil bagi dari nilai kekerasan $(\mathrm{kg})$ dan kekenyalan ( $\mathrm{mm}$ ) merupakan nilai tekstur daging ikan. Pengamatan tekstur dilakukan setiap empat hari sekali. Analisis data dilakukan dengan uji sidik ragam (anova) untuk mengetahui pengaruh perlakuan

\section{HASIL DAN BAHASAN}

\section{Hasil Penelitian Pendahuluan}

Dari hasil pengamatan selama percobaan pendahuluan diperoleh data laju sintasan ikan uji yang berasal dari kolam air deras dan keramba jaring apung pada media salinitas 5 dan 10 ppt yaitu berkisar antara $97-100 \%$ (rata-rata 98,6\% dan 98,7\%). Pada salinitas 15 ppt memperlihatkan mortalitas yang tinggi dan hanya bertahan selama 6 jam (Tabel 1)

Tabel 1. Rata-rata sintasan dari ikan mas pada salinitas yang berbeda selama 30 hari

Table 1. Average survival rate of common carp at different salinities during 30 days

\begin{tabular}{ccc}
\hline \multirow{2}{*}{$\begin{array}{c}\text { Media salinitas } \\
\text { Salinity of media }\end{array}$} & \multicolumn{2}{c}{$\begin{array}{c}\text { Sintasan } \\
\text { Survival rate (\%) }\end{array}$} \\
\cline { 2 - 3 } & $\begin{array}{c}\text { Kolam air deras } \\
\text { Running water }\end{array}$ & $\begin{array}{c}\text { Keramba jaring apung } \\
\text { Floating net cage }\end{array}$ \\
\hline 0 & 100.0 & 100.0 \\
5 & 97.9 & 98.2 \\
10 & 97.8 & 97.9 \\
\hline
\end{tabular}




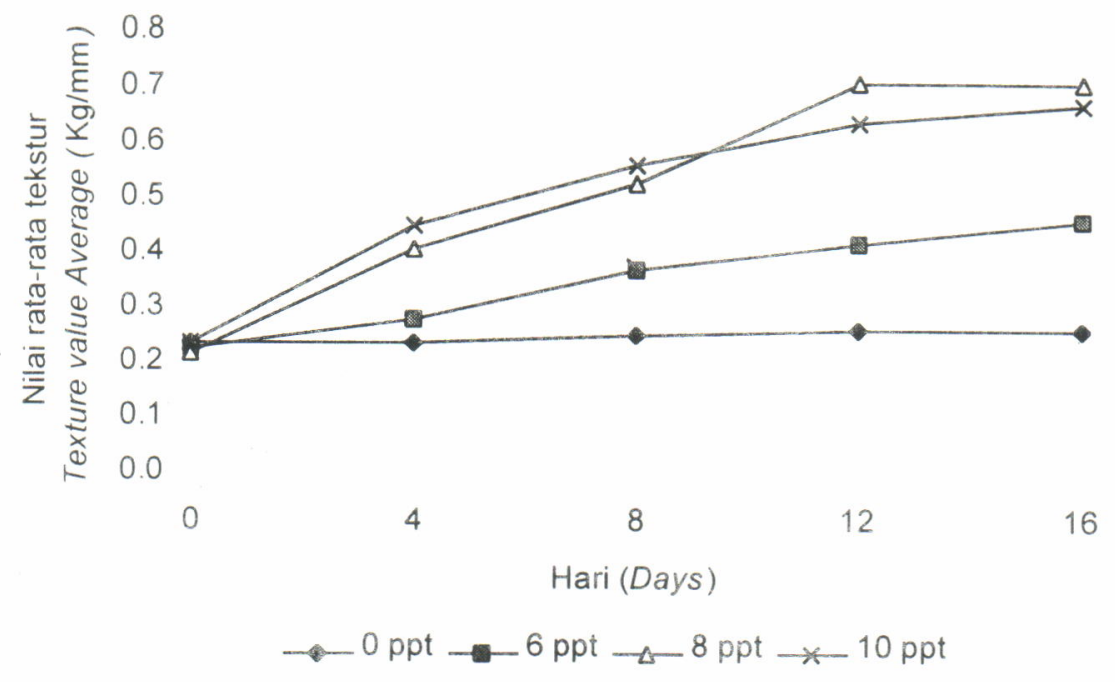

Gambar 1. Nilai rata-rata tekstur daging ikan mas $(\mathrm{kg} / \mathrm{mm})$ asal kolam air deras

Figure 1. Average value of texture of common carp meal $(\mathrm{kg} / \mathrm{mm})$ originated from running water

\section{Hasil Penelitian Lanjutan}

Hasil analisis statistik menunjukkan bahwa perlakuan cara budi daya kolam air deras dan keramba jaring apung, lama adaptasi, pemeliharaaan, dan tingkat salinitas berpengaruh nyata terhadap kualitas daging ikan mas, yang ditunjukkan dengan adanya interaksi antara ketiga faktor perlakuan tersebut.

Ikan mas yang berasal dari kolam air deras, menunjukkan tekstur daging tertinggi pada hari ke-12 dengan salinitas 8 ppt (Gambar 1). Untuk ikan mas yang berasal dari keramba jaring apung tekstur daging tertinggi diperoleh pada hari ke-16 dengan salinitas 10 ppt (Gambar 2). Semua perlakuan salinitas menunjukkan tekstur tertinggi secara nyata dibandingkan dengan kontrol $(p<0,05)$.

Perubahan tekstur daging ikan uji diduga dipengaruhi tidak hanya oleh faktor konsentrasi dan salinitas serta lamanya adaptasi, tetapi juga oleh faktor parameter lingkungan pemeliharaan, yaitu tersedianya organisme makanan dan adanya zatzat seperti oksigen terlarut, karbon dioksida, amonia, nitrat, dan ion hidrogen (Boyd \& Linkoppler, 1979). Selain itu media salinitas mempengaruhi kondisi in.

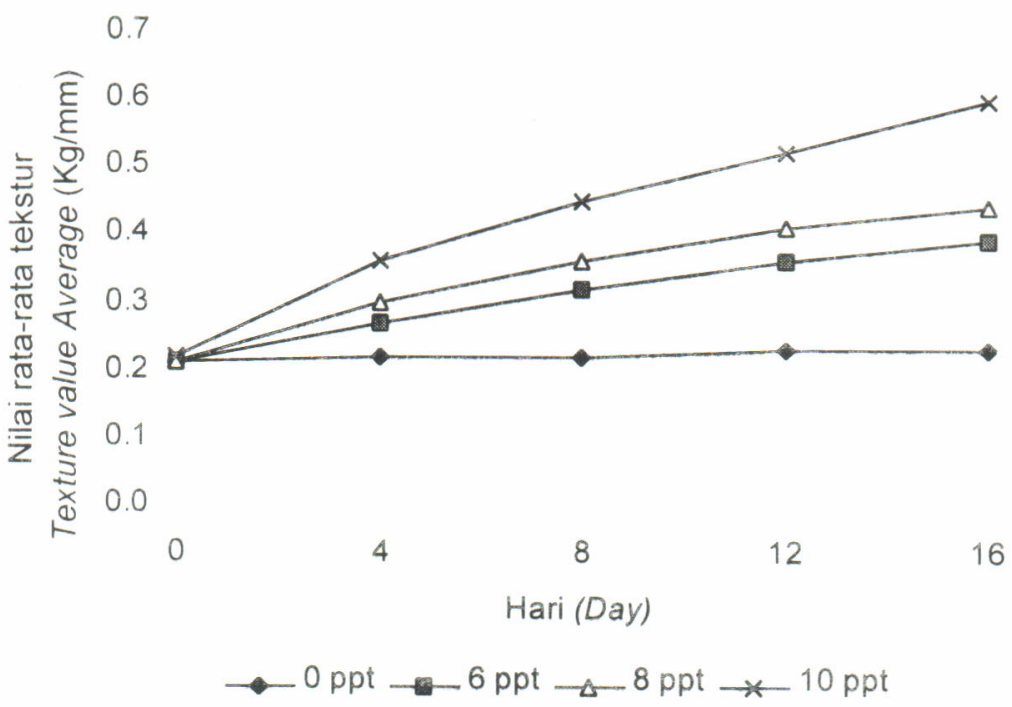

Gambar 2. Nilai rata-rat tekstur daging ikan mas $(\mathrm{kg} / \mathrm{mm})$ asal keramba jaring apung

Figure 2. Average value of texture of common carp meat $(\mathrm{kg} / \mathrm{mm})$ originated from floating cage 
Tabel 2. Kadar protein (\%) daging ikan mas *

Table 2. Protein content (\%) of common carp

\begin{tabular}{|c|c|c|c|c|c|}
\hline \multirow{2}{*}{$\begin{array}{l}\text { Asal ikan } \\
\text { Fish origin }\end{array}$} & \multirow{2}{*}{$\begin{array}{l}\text { Hari } \\
\text { day }\end{array}$} & \multicolumn{4}{|c|}{ Salinitas / Salinity (ppt) } \\
\hline & & 0 & 6 & 8 & 10 \\
\hline & & 14.00 & 14.26 & 15.16 & 15.21 \\
\hline Kolam air deras & 8 & 14.28 & 14.42 & 15.36 & 15.41 \\
\hline \multirow[t]{3}{*}{ Running water } & 12 & 14.31 & 15.53 & $16.27^{\star}$ & 15.89 \\
\hline & 16 & 14.31 & 15.54 & $16.27^{\star}$ & 16.27 \\
\hline & 4 & 12.07 & 14.78 & 14.97 & 15.00 \\
\hline Keramba jaring apung & 8 & 12.07 & 14.83 & 15.01 & 15.52 \\
\hline \multirow[t]{2}{*}{ Floating net cage } & 12 & 12.09 & 14.82 & 15.46 & 15.84 \\
\hline & 16 & 12.09 & 14.89 & 15.78 & $15.89^{*}$ \\
\hline
\end{tabular}

*) rata-rata protein basah dari 3 ulangan (wet basis, mean of 3 replicates)

ternal ikan dengan tekanan osmotik dan konsentrasi cairan tubuh merupakan salah satu faktor yang dipengaruhi dan berdampak terhadap elastisitas daging (Halver, 1972). Faktor tersebut berlaku sama pada ikan air tawar lainnya seperti ikan nila yang diberok dalam air laut selama dua minggu diperoleh tekstur daging yang lebih baik dibandingkan dengan empat minggu (Anggawati et al., 1991). Pada ikan gurami tekstur tertinggi diperoleh setelah diadaptasikan selama delapan hari pada salinitas 8 ppt (Setijaningsih, 1999).

Perbedaan sistem budi daya juga memberikan pengaruh yang nyata pada pencapaian homeostatis. Ikan yang dipelihara di kolam air deras, aktivitas fisik yang dilakukannya lebih intensif di mana komposisi jaringan otot berkembang lebih banyak, dengan akibatnya akan mendominasi komposisi jaringan penyusun daging ikan sehingga tekstur daging ikan lebih kompak.

Hal ini sejalan dengan hasil penelitian Tajerin et al. (1997), yang menyatakan bahwa ikan mas yang dipelihara di kolam air deras lebih baik tekstur dagingnya dibandingkan dengan ikan mas yang dipelihara di kolam air mengalir dan air tenang.

\section{Kandungan Protein}

Protein berperanan dalam menentukan kualitas tekstur daging ikan. Protein berfungsi dalam memperbaiki dan membentuk jaringan (daging ikan) (National Research Council,1977). Jenis protein yang berfungsi sebagai pembentuk jaringan ikat, yang tidak larut dalam air dan larutan garam yaitu protein stroma. Suzuki (1981) menyatakan bahwa kelompok protein stroma juga disebut skleroprotein dengan komponen yang terdiri atas kolagen dan elastin, letaknya pada miokomata dan membran sel yang berfungsi sebagai jaringan ikat.
Jenis protein ini pada media salinitas berperan dalam peningkatan tekstur melalui penggumpalan dan pembentukan jaringan pengikat. Semakin tinggi persentase protein yang terdapat pada daging semakin berkorelasi positif dengan tekstur daging ikan. Berdasarkan data pada Tabel 2 dapat dilihat bahwa perbedaan lamanya beradaptasi pada media salinitas menunjukkan kadar protein ikan uji pada akhir penelitian berbeda. Ikan yang berasal dari keramba jaring apung mempunyai kadar protein sebesar $15,89 \%$, sedangkan kadar protein ikan yang berasal dari kolam air deras adalah 16,27\%. Kadar protein ikan asal kolam air deras yang diadaptasi di salinitas 8 ppt pada hari ke-12 dan ke-16 adalah sama, sehingga dari segi efisiensi baik secara teknis maupun secara ekonomis dipilih bahwa adaptasi pada hari ke12 dengan salinitas $8 \mathrm{ppt}$ adalah yang optimum.

\section{Organoleptik Rasa}

Hasil uji organoleptik rasa ikan mas menunjukkan bahwa pada perbedaan tingkat salinitas memberikan rasa yang berbeda pada ikan asal kolam air deras maupun ikan asal keramba jaring apung (Gambar 3). Perbedaan tingkat salinitas, dapat memberikan pengaruh pada kemampuan ikan dari lingkungannya (Lovell \& Sackey, 1973).

Rasa yang disukai panelis tampaknya paralel dengan semakin lamanya ikan dipelihara pada media salinitas. Skor uji organoleptik rasa dari panelis untuk ikan asal kolam air deras dan ikan asal keramba jaring apung tidak berbeda nyata. Terdapat kecenderungan pada panelis tidak bisa membedakan rasa ikan yang berasal dari kolam air deras dan ikan asal keramba jaring apung yang dipelihara pada media salinitas.

Kandungan beberapa asam amino bebas, seperti prolin dan histidin dapat memberikan kelezatan rasa yang enak pada daging ikan (Ding et al.,1989). Hasil 


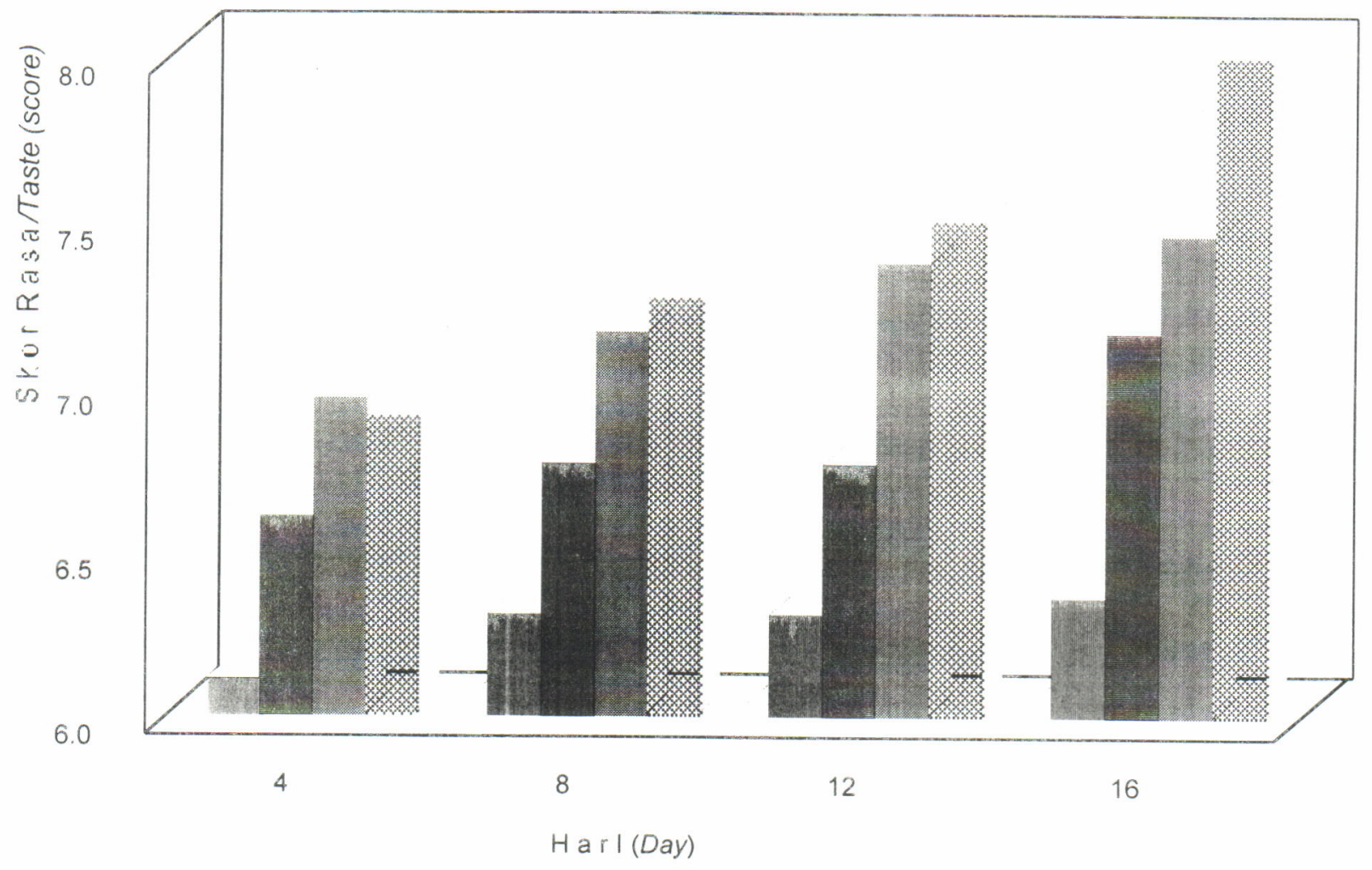

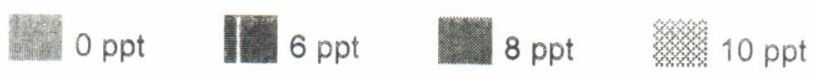

Gambar 3. Skor organoleptik pada rasa daging ikan mas

Figure 3. Organoleptic score of common carp meat taste

analisis asam amino yang berpengaruh terhadap cita terbentuk dari awal dimulainya penelitian sampai hari rasa menunjukkan asam amino esensial yang ke-16 adalah histidin dan prolin. Persentase asam

Tabel 3. Jenis asam amino (\%) pada ikan mas, sebelum dan pada akhir pemeliharaan

Table 3 Amino acid (\%) of common carp before and after culture period

\begin{tabular}{lcc}
\hline \multirow{2}{*}{ Asam amino (Amino acid) } & \multicolumn{2}{c}{ Kandungan (Content) (\%) } \\
\cline { 2 - 3 } & Awal (Begining) & Akhir (End) \\
\hline Glutamic acid & 1.47 & - \\
Serin & - & 0.96 \\
Glisin & 0.52 & - \\
Histidin & 1.11 & 1.33 \\
Arginin & 0.93 & 1.26 \\
Threonin & 0.44 & - \\
Alanin & - & 0.86 \\
Prolin & 0.93 & 1.33 \\
Tirosin & 2.84 & 2.54 \\
Valin & - & 0.88 \\
Metionin & - & 1.01 \\
Sistin & 1.87 & - \\
Isoleusin & 1.92 & - \\
Leusin & 1.03 & 0.51 \\
Phenil Alanin & - & 0.67 \\
Lisin & 0.71 & 1.3 \\
\hline
\end{tabular}


amino yang terbentuk menurut asal ikan terlihat pada Tabel 3

\section{KESIMPULANDAN SARAN}

1. Kualitas terbaik daging ikan mas asal kolam air deras dari segi tekstur dan rasa diperoleh pada hari ke-12 dengan salinitas 8 ppt.

2. Kualitas terbaik ikan asal keramba jaring apung diperoleh pada hari ke-16 dengan salinitas 10 ppt.

3. Kadar protein berkorelasi positif dengan kualitas daging ikan mas asal kolam air deras dan keramba jaring apung.

4. Asam amino esensial yang memberi rasa pada daging ikan di akhir penelitian adalah histidin dan prolin.

5. Penghitungan kelayakan ekonomi dikaitkan dengan upaya budi daya ikan mas di perairan tambak masih perlu dilakukan.

\section{DAFTARPUSTAKA}

Ardiwinata, R.O. 1981. Pemeliharaan Ikan Mas Jilid IV, Cetakan ke tiga. Penerbit sumur Bandung, Bandung. $140 \mathrm{pp}$

Anggawati, A.M., Yanti S., Wardana I., dan Sofyan I., 1991. Pemberokan (conditioning) ikan nila $\mathrm{m}$ e $\mathrm{r}$ a $\mathrm{h}$ dalam jaring apung di Teluk Banten. Bulletin Penelitian Perikanan No. 3. Puslitbang Perikanan, Jakarta. 135-141.

Boyd, C.E. dan Lichkoppler, F. 1979. Water Quality Management in Pond Fish Culture. $4^{\text {th }}$ printing. International Centre for Agriculture Experiment Station, Auburn. 359pp.
Ding,L.M., Yongging and Xianghua, L., 1989. Improvement of meat quality of grass carp, Ctenopharyngodon idellus (CUV.et Val.), p 148-152. In de Silva S.S. in: Fish Nutrition Research in Asia Proceeding of the Third Asian Fish Nutrition Network Meeting. Asian Fish Soc. Spec. Publ 4, 166 pp. Asian Fisheries Society, Manila Philippines

Halver, J.E. 1972. Fish Nutrition. Academic Press, New York. N.Y.713p

Lam, T.J. and Sharma, R. 1985. Effects of Salinity and Thiroxine on Larva survival, Growth and Development in the Carp Cyprinus carpio Aquaculture 44: 201-212

Lovell,R.T., \& L.A.Sackey, L.A. 1973. Absorption by channel catfish of earthymusty flavor compounds synthesized by culture of blue-green algae. Transaction of the American Fisheries Society. 102: 774-777.

National Research Council.1977. Nutrient Requirements of Warmwater Fishes. National Academy of Sciences, Washington D.C. p 71.

Schmidt, K. and Nielsen, 1988. Animal Physiology. Adaptation and environment. Cambridge University Press. Cambridge New York. New Ochelle, Melbourne, Sydney. 314pp.

Setijaningsih, L. 1999. Pengendalian bau lumpur pada daging ikan gurami. Warta Penelitian dan Pengembangan Pertanian. Badan Penelitian dan Pengembangan Pertanian. Vol 21 No 1. 1-2.

Soewarno, S.T. 1985. Penilaian Organoleptik untuk Industri Pangan dan Hasil Pertanian. Penerbit Batara Karya Aksara, Jakarta. 103 pp.

Tajerin, Mursidin, dan Baden M. 1997. Pengaruh kecepatan arus air dalam kolam terhadap tekstur daging ikan mas. Laporan Hasil Penelitian Balitkanwar. 